\title{
Loss of PPAR $\gamma$ expression by fibroblasts enhances dermal wound closure
}

Wei Sha', Katherine Thompson ${ }^{1}$, Jennifer South ${ }^{1}$, Murray Baron ${ }^{2}$ and Andrew Leask ${ }^{1,3^{*}}$

\begin{abstract}
Background: Peroxisome proliferator-activated receptor (PPAR) $\gamma$ may be a key regulator of connective tissue deposition and remodeling in vivo. PPARy expression is reduced in dermal fibroblasts isolated from fibrotic areas of scleroderma patients; PPAR $y$ agonists suppress the persistent fibrotic phenotype of this cell type. Previously, we showed that loss of PPARy expression in fibroblasts resulted in enhanced bleomycin-induced skin fibrosis. However, whether loss of PPARy expression in skin fibroblasts affects cutaneous tissue repair or homeostasis is unknown.

Results: Mice deleted for PPARy in skin fibroblasts show an enhanced rate of dermal wound closure, concomitant with elevated phosphorylation of Smad3, Akt and ERK, and increased expression of proliferating cell nuclear antigen (PCNA), collagen, $\alpha$-smooth muscle actin ( $\alpha$-SMA) and CCN2. Conversely, dermal homeostasis was not appreciably affected by loss of PPAR $\gamma$ expression.
\end{abstract}

Conclusion: PPAR expression by fibroblasts suppresses cutaneous tissue repair. In the future, direct PPAR antagonists and agonists might be of clinical benefit in controlling chronic wounds or scarring, respectively.

\section{Background}

If the dermis is injured, specialized fibroblasts called myofibroblasts repopulate the wound and synthesize and remodel new connective tissue [1]. Wound repair is very complex and dynamic, involving the interactions of multiple cell types and growth factors/cytokines; dysregulation of this process results in chronic wounds or fibrosis [2]. Thus, understanding the molecular mechanisms controlling the normal tissue repair program is likely to be of clinical relevance.

Expression of the nuclear receptor peroxisome proliferator-activated receptor (PPAR)- $\gamma$ is reduced in dermal fibroblasts isolated from fibrotic lesions of patients with the autoimmune connective tissue disease scleroderma (systemic sclerosis, SSc); moreover, the PPAR $\gamma$ agonist rosiglitazone reverses the persistent fibrotic phenotype of this cell type [3]. Normally, PPAR- $\gamma$ is bound to the retinoid $\mathrm{X}$ receptor (RXR) and co-repressors, preventing its binding to DNA; however, upon receptor ligation, the co-repressors are displaced from the PPAR- $\gamma /$ RXR complex allowing PPAR- $\gamma$ to bind PPAR- $\gamma$ response

\footnotetext{
* Correspondence: Andrew.leask@schulich.uwo.ca

'Department of Dentistry, Schulich School of Medicine and Dentistry,

Western University, Dental Sciences Bldg., London, ON, N6A 5C1, Canada Full list of author information is available at the end of the article
}

elements in the promoters of target genes [4]. The PPAR/RXR transcriptional complex plays a critical role in maintaining energy balance, which is dysregulated in conditions such as obesity, diabetes, and atherosclerosis [4].

An increasing body of evidence also suggests that PPAR- $\gamma$ plays a key role in connective tissue turnover, a key process involved with tissue remodeling [5]. Both in vivo and in vitro, PPAR- $\gamma$ agonists inhibit basal and transforming growth factor (TGF)- $\beta$-induced collagen deposition and myofibroblast differentiation [6,7]. Although loss of PPAR $\gamma$ expression in cultured mouse embryonic fibroblasts results in enhanced, constitutive Smad3 phosphorylation and collagen production [8], loss of PPAR $\gamma$ expression in cultured adult mouse fibroblasts appears to be insufficient to result in either Smad 3 activation or collagen production [9]. Instead, adult dermal fibroblasts lacking PPAR $\gamma$ expression show enhanced sensitivity to exogenously added TGF $\beta$ in terms of enhanced phosphorylation of Smad3 and expression of collagen/ $\alpha$-SMA mRNA [9]. Collectively, these data strongly suggest that PPAR $\gamma$ may play a role in fibrosis by enhancing cellular responses to TGF $\beta$.

Recently, we showed that mice harboring a fibroblastspecific deletion for PPAR $\gamma$ displayed an enhanced

C Biomed Central

(C) 2012 Sha et al; licensee BioMed Central Ltd. This is an Open Access article distributed under the terms of the Creative Commons Attribution License (http://creativecommons.org/licenses/by/2.0), which permits unrestricted use, distribution, and reproduction in any medium, provided the original work is properly cited. 
susceptibility to bleomycin-induced skin scleroderma [9]. These observations suggest that PPAR $\gamma$ might be an important regulator of cutaneous tissue repair and homeostasis in vivo; however, this hypothesis has yet to be tested. Herein, we subject mice harboring a fibroblast-specific deletion of PPAR $\gamma$ to the dermal punch model of cutaneous tissue repair. Moreover, we assess whether loss of PPAR $\gamma$ expression by skin fibroblasts affects dermal homeostasis. Our results reveal new insights into the role PPAR $\gamma$ plays in fibroblast biology.

\section{Results}

\section{Loss of PPARy expression in skin results in faster wound} closure

Mice deleted for PPAR $\gamma$ in fibroblasts $(\mathrm{K} / \mathrm{K})$ and wildtype littermate control $(\mathrm{C} / \mathrm{C})$ mice were generated and genotyped as previously described [9] (Figure 1A). Results were verified using Western blot and indirect immunofluorescence analysis of skin using an antiPPAR $\gamma$ antibody (Figure 1B, C). To examine whether loss of PPAR $\gamma$ expression in skin fibroblasts affected

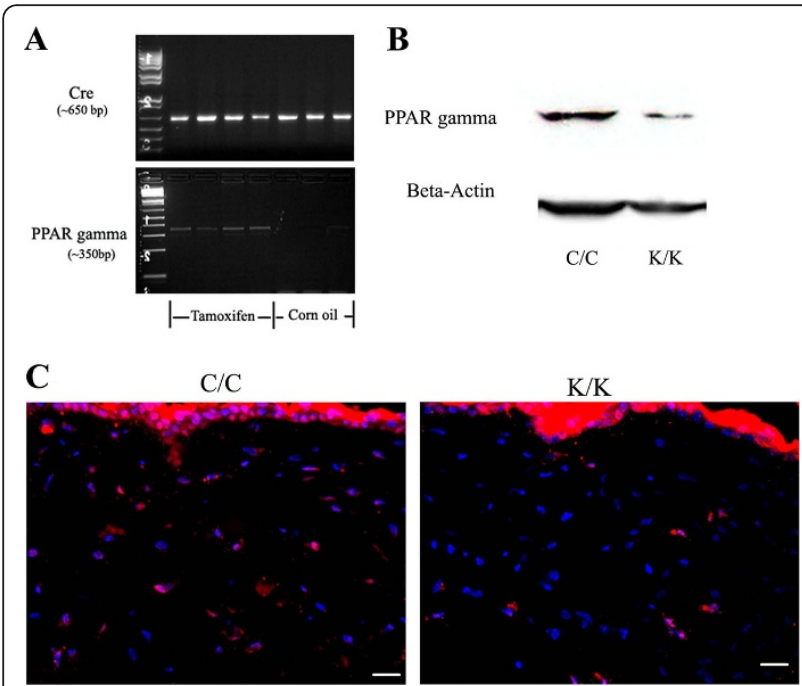

Figure 1 The deletion of PPAR $\gamma$ in skin fibroblasts. (A) Mice homozygous for loxP-PPARy and hemizygous for an allele enabling a tamoxifen-dependent cre recombinase to be expressed under the control of a fibroblast-specific collagen type I promoter/enhancer were injected with tamoxifen or corn oil to generate mice deleted $(K / K)$ or not $(C / C)$ for PPAR $\gamma$ in fibroblasts. PCR genotyping of PPAR $\gamma$ WT (C/C) or PPARy KO (K/K) mice. The upper panel shows the PCR result using primers detecting cre (approximately $650 \mathrm{bp}$ band); the bottom panel shows the PCR result with specific primers which amplify Exon I and Exon II-deleted PPAR $\gamma$ after tamoxifen injection (approximately $350 \mathrm{bp}$ band). (B) Western blot analysis of WT (C/C) and PPAR $\gamma$ KO (K/K) fibroblasts with an anti-PPAR $\gamma$ antibody. (C) Indirect immunofluorescence analysis of WT (C/C) and PPARy KO (K K) mice skin samples (original magnification $\times 40$, bar $=25 \mu \mathrm{m}$ ) using an anti- PPAR $y$ antibody. Red = PPAR gamma; Blue = DAPI. DAPI, 4',6-diamidino-2-phenylindole; PPAR $\gamma$, peroxisome proliferatoractivated receptor- $\gamma$. tissue repair, we subjected mice harboring a fibroblastspecific deletion for PPAR $\gamma(\mathrm{K} / \mathrm{K})$ and wild-type littermate control mice $(\mathrm{C} / \mathrm{C})$ to the dermal punch model of cutaneous tissue repair. PPAR $\gamma$ knockout mice $(\mathrm{K} / \mathrm{K})$ showed significantly increased wound closure three days, five days and seven days post-wounding; however, in both sets of mice, wound closure was essentially complete 10 days post-wounding (Figure 2A, B). The fact that mice harboring a fibroblast-specific deletion for PPAR $\gamma(K / K)$ showed an increased rate of tissue repair was confirmed when skin of mice (seven days postwounding) were examined histologically using $\mathrm{H}$ \& $\mathrm{E}$ staining (Figure 3A). Thus, in skin, loss of PPAR $\gamma$ increased the kinetics of wound closure

As loss of PPAR $\gamma$ resulted in an enhanced rate of tissue repair, we assessed whether loss of PPAR $\gamma$ also promoted collagen deposition. Blind histological analysis of trichrome-stained sections showed a greater collagen score in wounded PPAR $\gamma(\mathrm{K} / \mathrm{K})$ compared to control $(\mathrm{C} / \mathrm{C})$ mice (Figure $3 \mathrm{~B}, \mathrm{C})$. Assessment of collagen content using an anti-type I collagen antibody (Figure 3D, E) further confirmed that animals deficient in PPAR $\gamma$ possessed elevated collagen levels at day 7 post wounding. We then assessed the effect of loss of PPAR $\gamma$ on myofibroblast induction. Immunohistochemical analysis showed greater expression of a-SMA in day 7 and day 10 wounds of PPAR $\gamma$ knockout $(\mathrm{K} / \mathrm{K})$ mice compared to control $(\mathrm{C} / \mathrm{C})$ mice (Figure 4A, B). Western blot analysis on protein samples prepared from control and bleomycin-treated animals further confirmed elevated a-SMA production in day 7 wounds of PPAR-deficient $(\mathrm{C} / \mathrm{C})$ mice compared to control $(\mathrm{K} / \mathrm{K})$ mice (Figure $4 \mathrm{C}$ ). Fewer neutrophils were found in the wounds of PPARdeficient $(\mathrm{C} / \mathrm{C})$ mice compared to control $(\mathrm{K} / \mathrm{K})$ mice (Figure 4D), consistent with the increased rate of wound resolution observed in these mice. Furthermore, PCNA (a marker of cell proliferation) and CCN2 (a marker of tissue repair and fibrosis) expression were also significantly induced in the skin of day 7 and day 10 PPAR -deficient $(\mathrm{C} / \mathrm{C})$ mice compared to control $(\mathrm{K} / \mathrm{K})$ mice (Figure 5A, B). Similarly, elevated CCN2 mRNA expression was observed in PPAR-deficient fibroblasts (Figure 5C). Intriguingly, troglitazone, a PPAR $\gamma$ agonist, decreased CCN2 mRNA expression in both wild-type and PPAR $\gamma$-deficient fibroblasts (Figure $5 \mathrm{C}$ ) suggesting that troglitazone operates through PPAR-independent mechanisms (Figure 5C).

In skin fibroblasts, loss of PPAR $\gamma$ has been shown to result in enhanced phosphorylation of Smad3 in response to bleomycin or TGF $\beta$ [9]. Consistent with these data, we showed, using indirect immunofluorescence with an anti-phospho-Smad3, that Smad3 phosphorylation was enhanced seven days post-wounding in PPAR $\gamma$-deficient animals (Figure 6, p-Smad3). Moreover, 


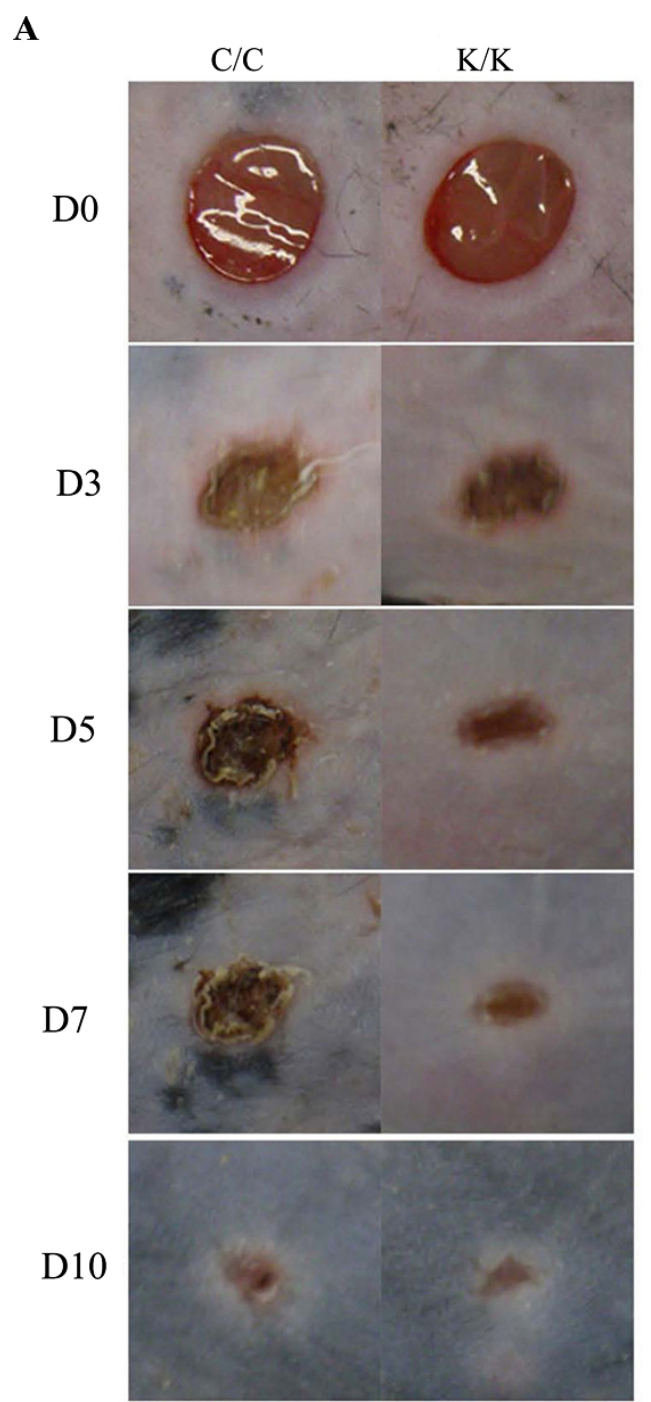

$\mathbf{B}$

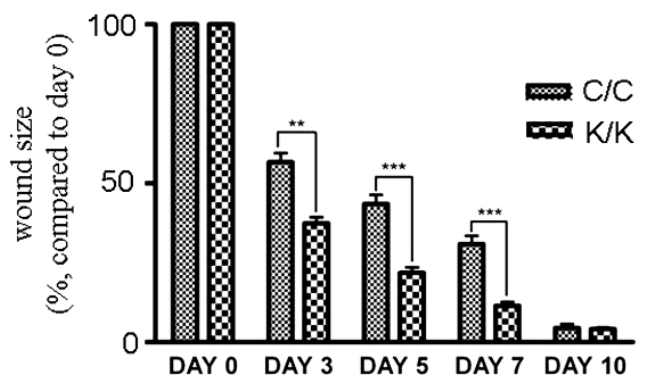

Figure 2 Wound closure is faster in PPAR $\gamma \mathrm{KO}(\mathrm{K} / \mathrm{K})$ mice than WT (C/C) mice. (A) Photography of wound sites at different time points after wounding ( $N \geq 12$ for each time point, four wounds for each mouse) (B) Quantification of wound size at different time points after wounding. Asterisks indicate significant differences between WT and KO groups $\left({ }^{* *}=P<0.01 ;{ }^{* *}=P<0.001\right)$. D, day. PPAR $\gamma$, peroxisome proliferator-activated receptor- $\gamma$. enhanced phosphorylation of Akt, a protein that is phosphorylated downstream of TGF $\beta$ and has previously been shown to be activated in fibrosis and to be modified by PPAR $\gamma$ [10-14], was also observed in the skin of day 7 and day 10 wounds of PPAR $\gamma$-deficient animals (Figure 6, p-Akt). Finally, enhanced phosphorylation of ERK, a protein that is also phosphorylated downstream of TGF $\beta$ and shown to be modified by PPAR $\gamma$ [14-17], was also observed in the skin of day 7 and day 10 wounds of PPAR $\gamma$-deficient animals (Figure 6, p-ERK). Collectively, these data indicate that loss of PPAR $\gamma$ expression in skin results in elevated pro-fibrotic signaling.

\section{Loss of PPARy does not appreciably affect dermal homeostasis}

A priori, we would have expected that, as loss of PPAR $\gamma$ resulted in increased Smad3 and Akt phosphorylation in response to bleomycin or punch wounding [9], this report, loss of PPAR $\gamma$ expression by itself might have been sufficient to result in skin fibrosis. However, PPAR $\gamma$-deficient skin did not show significant alterations in skin thickness or matrix accumulation even four months after the PPAR $\gamma$ gene was deleted (Figure 7A, B).

Collectively, our results indicate that, in vivo, PPAR $\gamma$ normally acts in dermal fibroblasts to suppress fibrogenic responses.

\section{Discussion}

In this study, we tested the effect of loss of PPAR $\gamma$ in dermal fibroblasts on cutaneous tissue repair in vivo. PPAR $\gamma$-deficient mice showed enhanced responsiveness to tissue injury, as shown by increased wound closure on days three, five, seven and ten post-wounding, increased collagen production, the appearance of $\alpha$ SMA-expressing myofibroblasts, elevated CCN2 expression and enhanced Smad3/Akt phosphorylation. These results are consistent with previous observations that PPAR $\gamma$-deficient fibroblasts showed enhanced sensitivity to TGF $\beta 1$ and that PPAR $\gamma$-deficient mice showed increased susceptibility to bleomycin-induced skin fibrosis $[8,9]$. These data also agree with prior studies showing that, in fibroblasts, PPAR $\gamma$ agonists block TGF $\beta$ induced $\alpha$-SMA and collagen expression [6]. Moreover, we showed that, although CCN2 mRNA was elevated in PPAR $\gamma$-knockout fibroblasts, troglitazone suppressed CCN2 mRNA in both wild-type and PPAR $\gamma$-knockout fibroblasts. Although it is possible that these PPAR $\gamma$ agonists were active due to the small residual expression of PPAR $\gamma$ in PPAR $\gamma$ knockout fibroblasts, these data do not exclude the notion that thiazolidinediones such as troglitazone have potent 'off-target' effects independent 


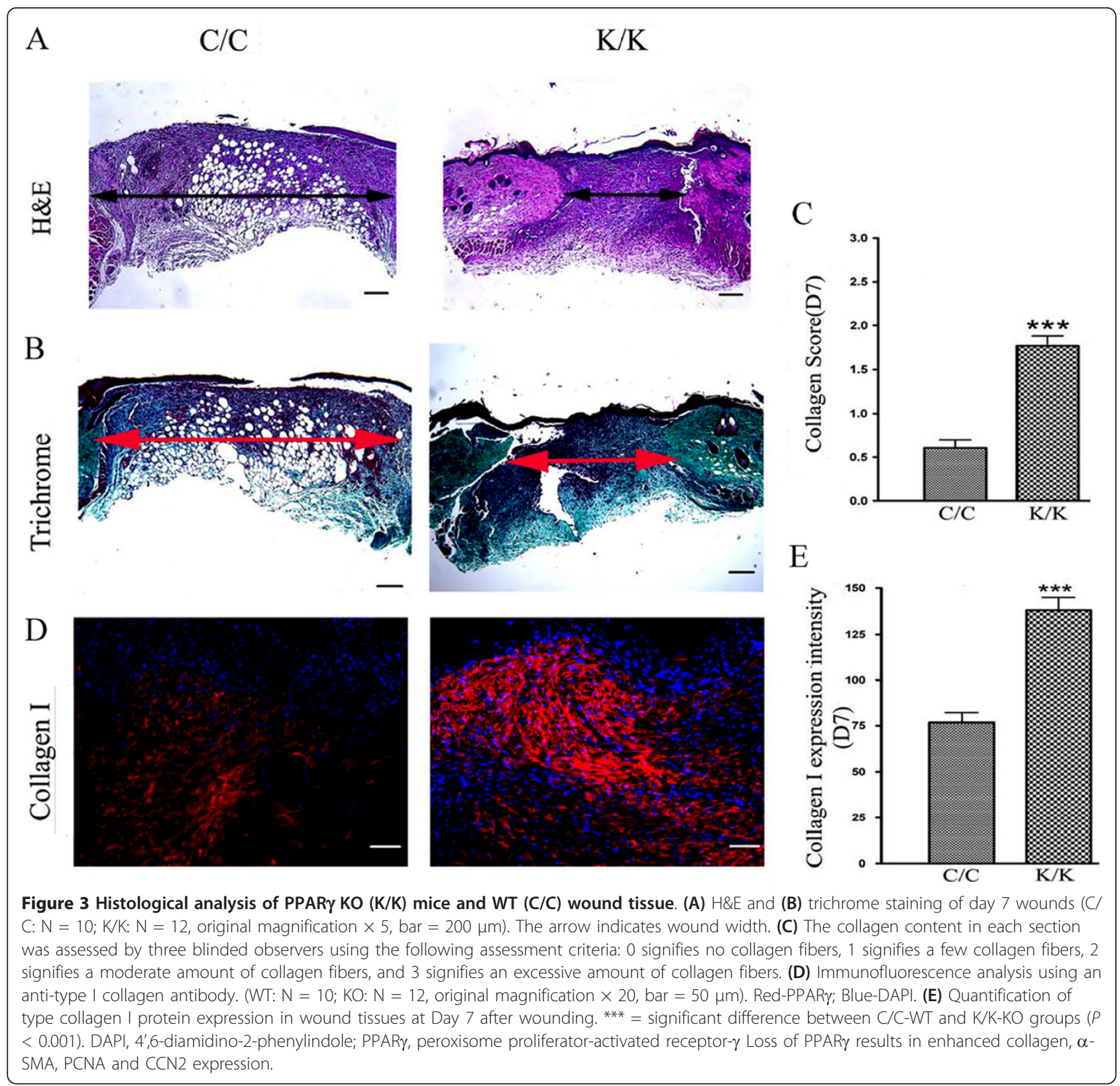

of PPAR $\gamma$ itself [18]. Nonetheless, these data collectively suggest that PPAR $\gamma$ normally suppresses fibrogenic responses in vivo and also support the notion that developing novel classes of direct PPAR $\gamma$ agonists/antagonists is warranted.

We found that long-term (up to four months) deletion of PPAR $\gamma$ did not appreciably affect dermal homeostasis. This result is consistent with our previous data showing that mice deficient in PPAR $\gamma$ expression in fibroblasts (approximately six weeks post-deletion of PPAR $\gamma$ ), although possessing enhanced susceptibility to bleomycin-induced skin fibrosis, possessed no detectable alterations in skin structure [9]. PPAR $\gamma$ is known to upregulate the tumor suppressor PTEN; loss of PTEN expression by dermal fibroblasts results in skin fibrosis due to an increase in Akt phosphorylation [13,18]. Intriguingly, we found that PTEN expression was increased and not decreased in the dermis of PPAR $\gamma$ knockout mice (data not shown). These observations suggest that PPAR $\gamma$ knockout mice may upregulate PTEN expression to compensate for the loss of PPAR $\gamma$ expression by dermal fibroblasts and provide a plausible explanation why dermal homeostasis was not appreciably altered in PPAR $\gamma$ knockout mice and injury, whether caused by bleomycin or by dermal punch wounding, is required to elicit a phenotype in PPAR $\gamma$ knockout animals. 

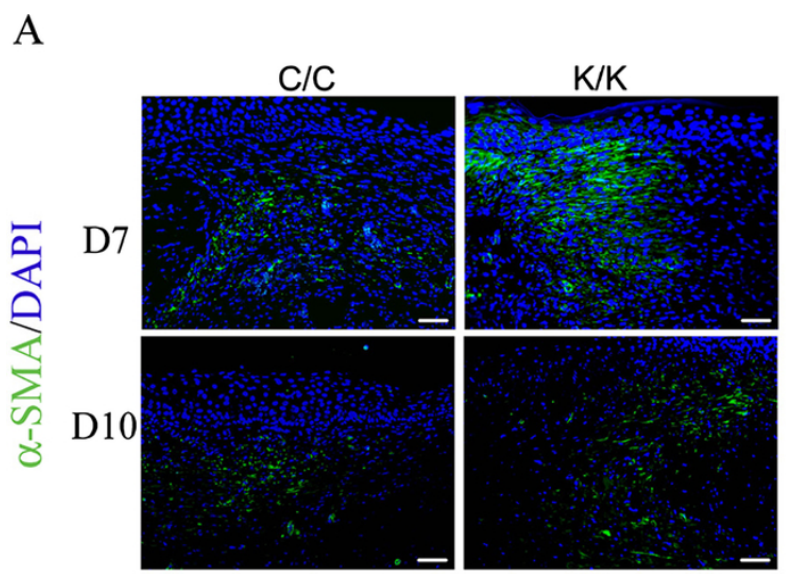

$\mathrm{C}$

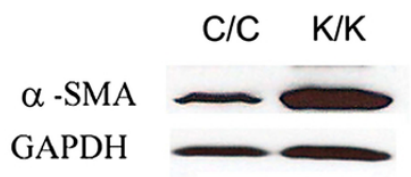

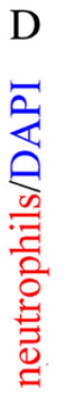

B

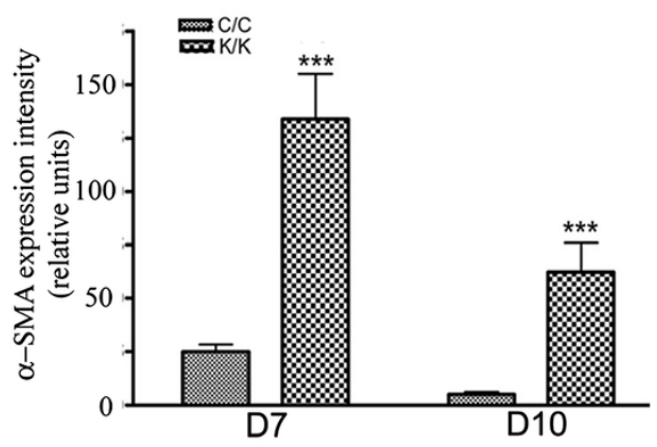

$\mathrm{E}$

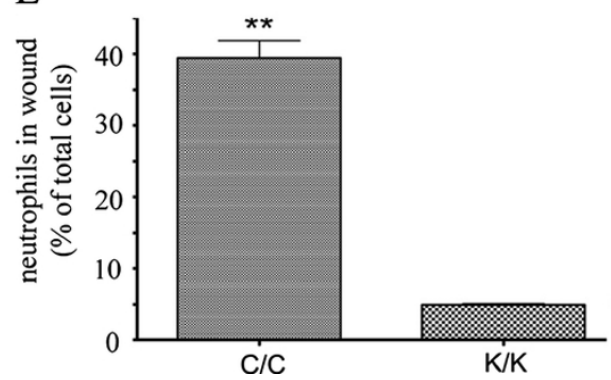

Figure 4 Alpha-SMA expression is enhanced in PPAR $\gamma$ KO (K/K) wound tissue (day 7 and day 10 post-wounding). (A) Indirect immunofluorescence analysis of WT (C/C) and PPAR $K O(K / K)$ mice with an anti- $\alpha$-SMA antibody (C/C: $N=10 ; K / K$ : $N=12$, original

magnification $\times 20$, bar $=50 \mu \mathrm{m}$ ). Green, $\alpha$-SMA; Blue, DAPI. (B) Quantification of $\alpha$-SMA expression intensity in wound tissues at day 7 and day 10 after wounding. (C) Western blot of $\alpha$-SMA expression in WT (C/C) and PPAR $\gamma$ KO (K/K) wound tissues at day 7 after wounding. GAPDH = loading control. (D) Indirect immunofluorescence analysis of WT (C/C) and PPAR $\mathrm{KO}(\mathrm{K} / \mathrm{K})$ mice with an anti-neutrophil antibody (C/C: N = 10; KK: $N=12$, original magnification $\times 20$, bar $=100 \mu \mathrm{m}$ ). Red, neutrophils; Blue, DAPI. (E) Quantification of neutrophils in wound tissues at day 7 after wounding. Asterisks indicate a significant difference between $C / C$ and $K / K$ groups $\left({ }^{* *}=P<0.01 ;{ }^{* * *}=P<0.001\right.$ ). DAPI, 4',6-diamidino-2phenylindole; PPAR $\gamma$, peroxisome proliferator-activated receptor- $\gamma$.

\section{Conclusion}

In summary, our studies examining the involvement in PPAR $\gamma$ in skin indicate that PPAR $\gamma$ normally acts in fibroblasts to retard tissue repair. These results suggest that direct PPAR $\gamma$ agonists and antagonists might be used to control the tissue repair program, for example, by suppressing scarring or by promoting the closure of chronic wounds.

\section{Methods}

Generation of PPAR $\gamma$ conditional knockout mice

Mice, hemizygous for an allele expressing tamoxifen-inducible Cre-recombinase (under the control of a fibroblastspecific regulatory sequence from the proa2(I) collagen gene [19]) and homozygous for a loxP-PPAR $\gamma$ allele, were generated as described previously [9]. Mice deleted (K/K) or not $(\mathrm{C} / \mathrm{C})$ for PPAR $\gamma$ in fibroblasts were generated by treating three-week-old mice each day for five days with tamoxifen (4-hydroxitamoxifen, Sigma, St. Louis, MO, USA) in corn oil $(0.1 \mathrm{ml}$ of $10 \mathrm{mg} / \mathrm{ml})$ or corn oil. Deletion of PPAR $\gamma$ was verified by PCR genotyping (Jackson Laboratories, Bar Harbor, ME, USA). $\gamma$ All animal protocols were approved by the regulatory authority of the appropriate experimental animal committee.

Cell culture, immunofluorescence and Western analysis Dermal fibroblasts, isolated from explants (four- to sixweek-old animals) as described, were subjected to 

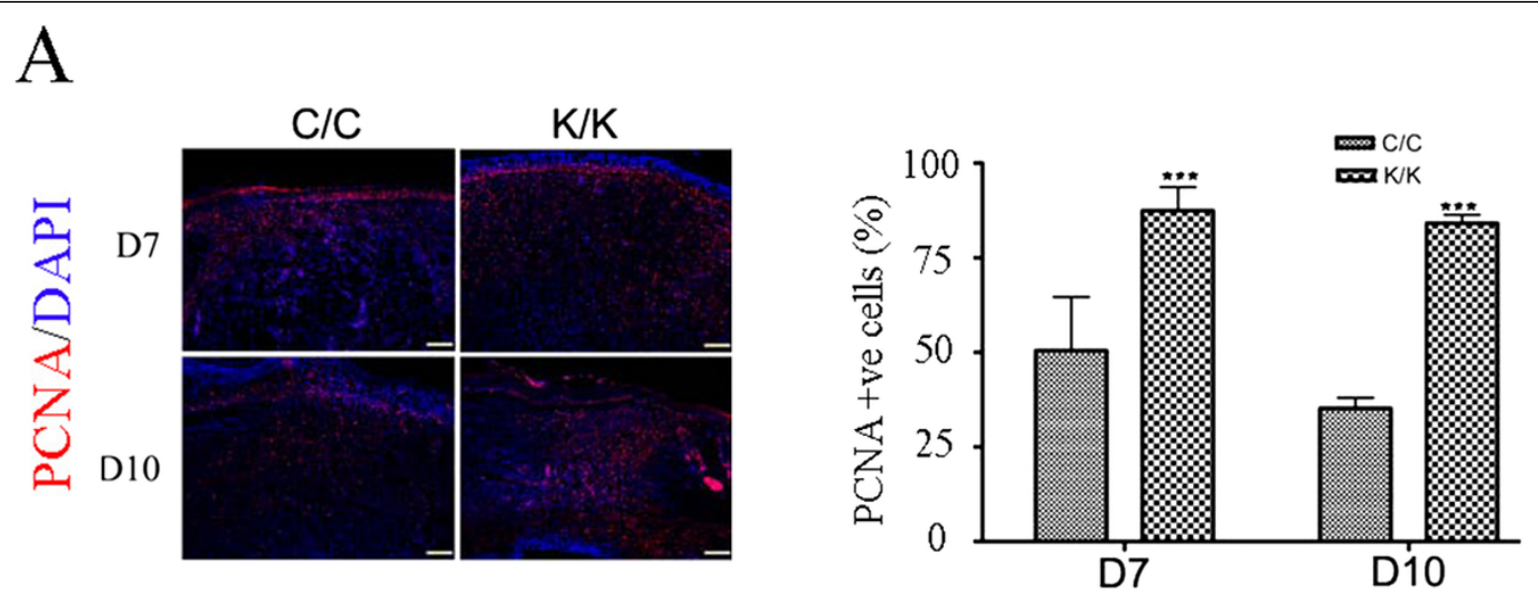

B
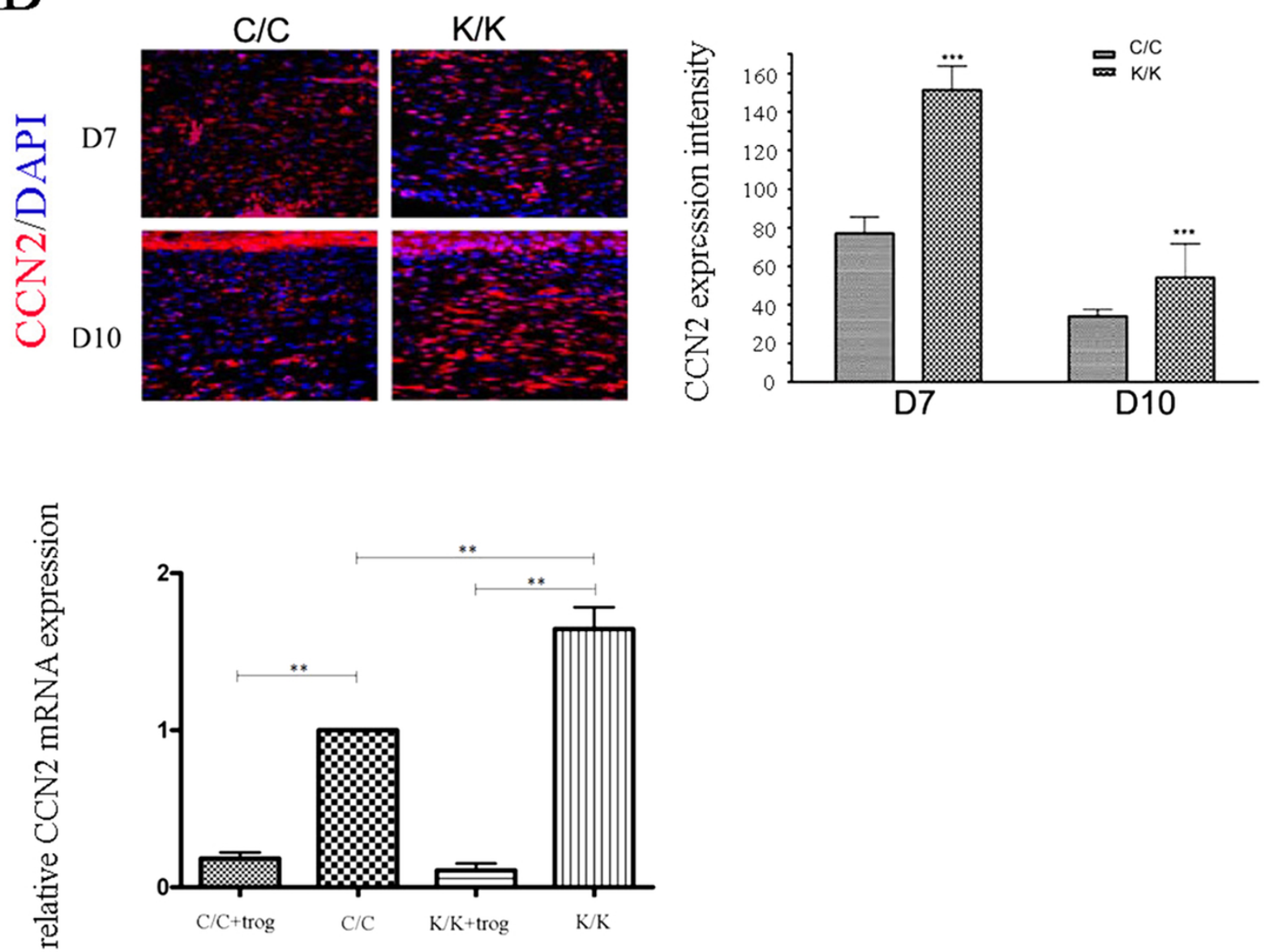

Figure 5 PCNA and CCN2 expression is enhanced in PPAR $\gamma$ KO (K/K) fibroblasts. Indirect immunofluorescence analysis of WT (C/C) and PPARy KO (K/K) mice (day 7 and 10 post-wounding) with (A) an anti-PCNA antibody and (B) an anti-CCN2 antibody $(C / C: N=10 ; K / K: N=12$, original magnification $\times 20$, bar $=50 \mu \mathrm{m})$. Red, CCN2;Blue, DAPI. ${ }^{* * *}=$ indicates significant difference between $\mathrm{C} / \mathrm{C}$ and $\mathrm{K} / \mathrm{K}$ groups $(P<0.001)$. (C) Real time PCR analysis of WT (C/C) and PPARy KO (K/K) fibroblasts treated with or without troglitazone (40 $\mu \mathrm{M}, 24$ hours). Primers detecting CCN2 and $18 S$ mRNAs were used. Expression relative to CCN2 expression in untreated WT (C/C) fibroblasts is shown. Average +/- standard deviation $(N=3)$ is shown. ${ }^{* *}=$ significant difference between groups $(P<0.01)$. Note that CCN2 mRNA expression was elevated in (K/K) fibroblasts; troglitazone (+trog) reduced CCN2 mRNA expression in both (C/C) and (K/K) fibroblasts indicating that troglitazone operated independent of PPAR $\gamma$. DAPI, 4',6-diamidino-2-phenylindole; PCNA, proliferating cell nuclear antigen.; PPAR $\gamma$, peroxisome proliferator-activated receptor- $\gamma$ Loss of PPAR $\gamma$ results in enhanced Smad3, Akt and ERK phosphorylation. 


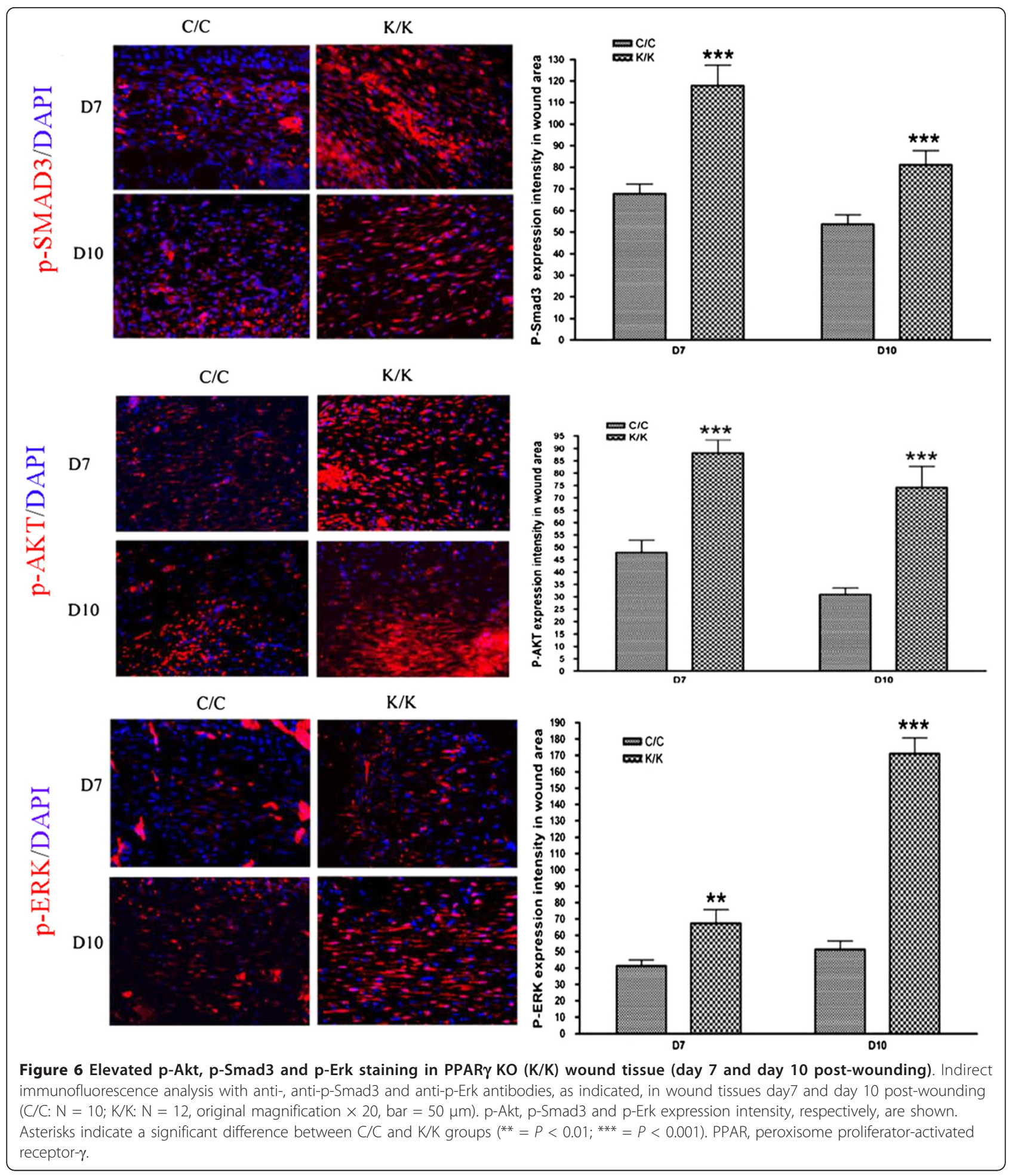

indirect immunofluorescence analysis followed by an appropriate secondary antibody (Jackson Immunoresearch, West Grove, PA, USA) as described [9]. Photography (Zeiss Axiphot) was performed using a digital camera (Empix, Mississauga, ON, Canada). For some assays, cells were lysed in 2\% SDS, proteins quantified (Fisher, Nepean, ON, Canada) and subjected to Western blot analysis [9]. Antibodies used were: anti-a-SMA (Sigma,1:3000), anti- $\beta$-actin (1:5000, Sigma) and antiPPAR $\gamma$ (Santa Cruz, Santa Cruz, CA, USA,1:500). $\gamma$ 


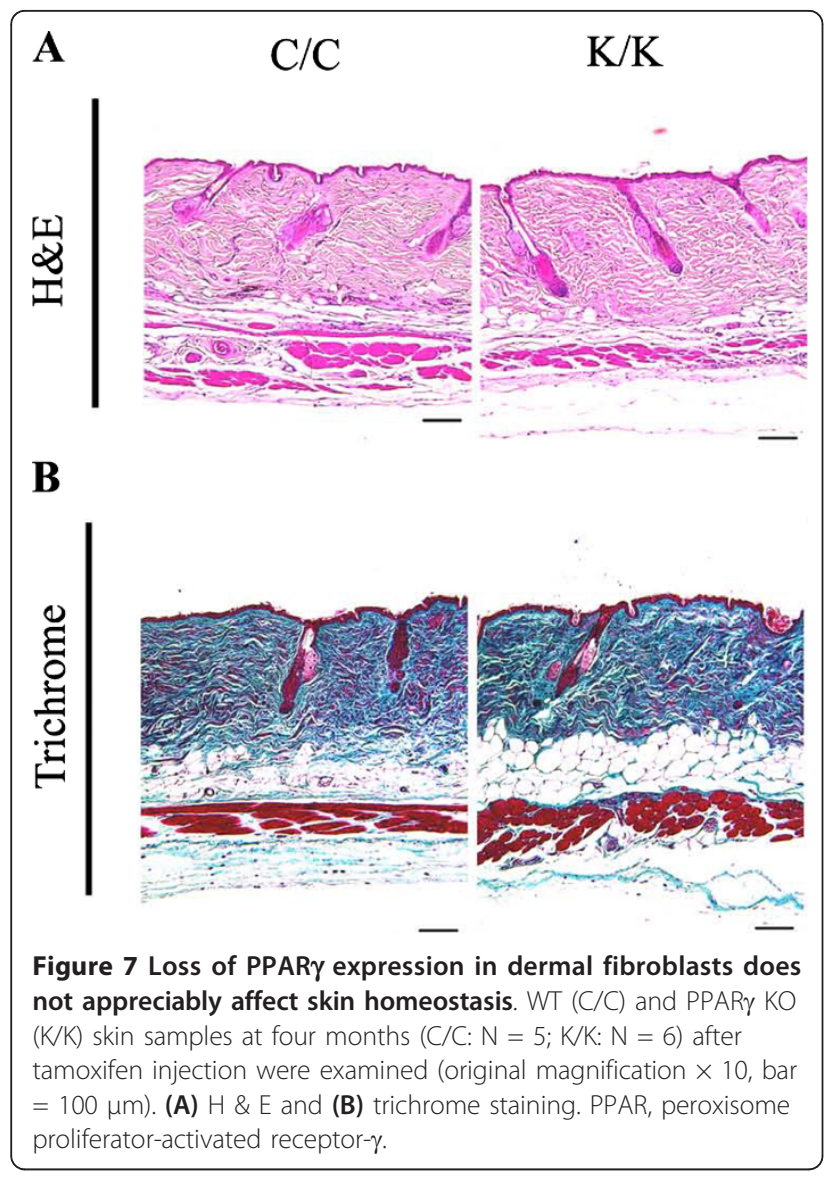

Human dermal fibroblasts were purchased (American Type Culture Collection, Manassas, VA, USA). Cells were grown in (D)MEM, 10\% fetal bovine serum (Life Technologies, Burlington, ON, Canada).

\section{Assessment of collagen content}

To assess the effects of PPAR $\gamma$ deletion on collagen synthesis, trichrome collagen stain was used. Collagen content in each section was assessed by three blinded observers using the following assessment criteria: 0 signifies: no collagen fibers; 1 signifies: few collagen fibers; 2 signifies: moderate amount of collagen fibers; 3 signifies: excessive amount of collagen fibers.

\section{Immunohistochemistry}

Non-specific immunoglobulin G (IgG) binding was blocked by incubating sections with BSA $(0.1 \%)$ in PBS for 1 hour and then incubated with primary antibody in a humidified chamber and left overnight at $4^{\circ} \mathrm{C}$. Next, sections were washed and incubated with a secondary antibody for 1 hour. Primary antibodies used were: PPAR $\gamma$ (Santa Cruz, Rabbit, sc-7196, 1:500) PTEN (Cell Signaling, Pickering, ON, Canada, \#9559, Rabbit, 1:500) CCN2 (Abcam, Cambridge, MA, USA, ab6992, Rabbit,
1:250), $\alpha$-SMA (Sigma, A5228, mouse, 1:2000); Colla2 (Santa Cruz, sc-28654, rabbit, 1:500), PCNA: (Abcam, ab2426-1, rabbit, 1:500); p-SMAD3: (Abcam, rabbit, ab52903, 1:200); p-AKT (Rockland Immunochemicals, Gilbertsville, PA, USA, 200-301-268, mouse), (1:500); pERK (Cell Signaling, \#9101, rabbit, 1:500) and neutrophil marker (Santa Cruz, sc-59338, rat,1:100). Secondary antibodies (Jackson Immunoresearch, 1:400) were: Dylight 488 conjugated donkey anti-mouse (711-485150); Dylight 594 conjugated donkey anti-rabbit (711485-152); Dylight 594 conjugated donkey anti-mouse (715-515-150) and Dylight 594 conjugated donkey antirat (712-516-150).

\section{Real-time PCR}

Real-time PCR to detect the expression of target genes was performed essentially as previously described $[20,21]$. Cells were cultured until 50\% confluence and treated for 24 hours with dimethyl sulfoxide (DMSO) or troglitazone ( $40 \mu \mathrm{M}$, EMD Biosciences, Billerica, MA, USA) and total RNA was isolated (RNeasy; QIAGEN, Toronto, ON, Canada). Total RNA (25 ng) was reverse transcribed, amplified using Taq-Man Assays-onDemand in the presence One-Step MasterMix and detected using the ABI Prism 7900 HT sequence detector (Life Technologies). Triplicate samples were run, and expression values for $\mathrm{CCN} 2$ were standardized to values obtained with control $18 \mathrm{~S}$ primers using the $\Delta \Delta \mathrm{Ct}$ method.

\section{Statistics}

Statistical analysis was done using one way analysis of variance (ANOVA) and Tukey's post-hoc test on Graphpad Prism 4 software.

\section{Abbreviations}

bp: Base pair; BSA: Bovine serum albumin; DAPI: 4',6-diamidino-2phenylindole; (D)MEM: (Dulbecco's) modified Eagle's medium; H \& E: Hematoxylin and eosin; IgG: Immunoglobulin G; PCNA: Proliferating cell nuclear antigen; PCR: Polymerase chain reaction; PPAR: Peroxisome proliferator-activated receptory; RXR: Retinoid X receptor; $\alpha$-SMA: $\alpha$-smooth muscle actin; TGF- $\beta$ : Transforming growth factor- $\beta$.

\section{Acknowledgements}

This work is supported by grants from the Canadian Institutes of Health Research (to AL and MB) and the Ontario Scleroderma Society (to AL). AL is a member of the Canadian Scleroderma Research Group New Emerging Team. WS and KT were the recipients of salary awards from the Canadian Scleroderma Research Group.

\section{Author details}

'Department of Dentistry, Schulich School of Medicine and Dentistry, Western University, Dental Sciences Bldg., London, ON, N6A 5C1, Canada. 2Department of Rheumatology, Jewish General Hospital, 3755 Cote St. Catherine Rd., Montreal, QC, H3T 1E2, Canada. ${ }^{3}$ Department of Physiology and Pharmacology, Schulich School of Medicine and Dentistry, Western University, Dental Sciences Bldg., London, ON, N6A 5C1, Canada. 


\section{Authors' contributions}

WS conducted the in vivo studies and tissue analysis. KT and JS carried out the cell culture and real time PCR analysis. MB participated in design of the study. AL conceived of the study, and participated in its design and coordination. WS, KT, MB and AL wrote the paper. All authors read and approved the final manuscript.

\section{Competing interests}

The authors declare that they have no competing interests.

Received: 4 January 2012 Accepted: 13 April 2012

Published: 13 April 2012

\section{References}

1. Tomasek JJ, Gabbiani G, Hinz B, Brown RA: Myofibroblasts and mechanoregulation of connective tissue remodelling. Nat Rev Mol Cell Biol 2003, 3:349-363.

2. Elliott CG, Hamilton DW: Deconstructing fibrosis research: do pro-fibrotic signals point the way for chronic dermal wound regeneration? J Cell Commun Signal 2011, 5:301-315.

3. Shi-wen X, Eastwood M, Stratton RJ, Denton CP, Leask A, Abraham DJ: Rosiglitazone alleviates the persistent fibrotic phenotype of lesional skin scleroderma fibroblasts. Rheumatology (Oxford) 2010, 49:259-263.

4. Plutzky J: The PPAR-RXR transcriptional complex in the vasculature: energy in the balance. Circ Res 2011, 108:1002-1016.

5. Wei J, Bhattacharyya S, Varga J: Peroxisome proliferator-activated receptor $\gamma$ innate protection from excessive fibrogenesis and potential therapeutic target in systemic sclerosis. Curr Opin Rheumatol 2010, 22:671-676.

6. Burgess HA, Daugherty LE, Thatcher TH, Lakatos HF, Ray DM, Redonnet M, Phipps RP, Sime PJ: PPARgamma agonists inhibit TGF-beta induced pulmonary myofibroblast differentiation and collagen production: implications for therapy of lung fibrosis. Am J Physiol Lung Cell Mol Physiol 2005, 288:L1146-L1153.

7. Wu M, Melichian DS, Chang E, Warner-Blankenship M, Ghosh AK, Varga J: Rosiglitazone abrogates bleomycin-induced scleroderma and blocks profibrotic responses through peroxisome proliferator-activated receptor-gamma. Am J Pathol 2009, 174:519-533.

8. Ghosh AK, Wei J, Wu M, Varga J: Constitutive Smad signaling and Smaddependent collagen gene expression in mouse embryonic fibroblasts lacking peroxisome proliferator-activated receptor-gamma. Biochem Biophys Res Commun 2008, 374:231-236.

9. Kapoor M, McCann M, Liu S, Huh K, Denton CP, Abraham DJ, Leask A: Loss of PPARy in mouse fibroblasts results in increased susceptibility to bleomycin-induced skin fibrosis. Arthritis Rheum 2009, 60:2822-2829.

10. Shi-wen X, Stanton LA, Kennedy L, Pala D, Chen Y, Howat SL, Renzoni EA, Carter DE, Bou-Gharios G, Stratton RJ, Pearson JD, Beier F, Lyons KM, Black CM, Abraham DJ, Leask A: CCN2 is necessary for adhesive responses to transforming growth factor-beta1 in embryonic fibroblasts. J Biol Chem 2006, 281:10715-10726.

11. Kulkarni AA, Thatcher TH, Olsen KC, Maggirwar SB, Phipps RP, Sime PJ: PPAR- $\gamma$ ligands repress TGF $\beta$-induced myofibroblast differentiation by targeting the PI3K/Akt pathway: implications for therapy of fibrosis. PLoS One 2011, 6:e15909.

12. Xu SW, Liu S, Eastwood M, Sonnylal S, Denton CP, Abraham DJ, Leask A: Rac inhibition reverses the phenotype of fibrotic fibroblasts. PLoS One 2009, 4:e7438.

13. Parapuram SK, Shi-wen X, Elliott C, Welch ID, Jones H, Baron M, Denton CP, Abraham DJ, Leask A: Loss of PTEN expression by dermal fibroblasts causes skin fibrosis. J Invest Dermatol 2011, 131:1996-2003.

14. Huang W, András IE, Rha GB, Hennig B, Toborek M: PPARa and PPARY protect against HIV-1-induced MMP-9 overexpression via caveolaeassociated ERK and Akt signaling. FASEB J 2011, 25:3979-3988.

15. Leask A, Holmes A, Black CM, Abraham DJ: Connective tissue growth factor gene regulation. Requirements for its induction by transforming growth factor-beta 2 in fibroblasts. J Biol Chem 2003, 278:13008-13015.

16. Zhang M, Fraser D, Phillips A: ERK, p38, and Smad signaling pathways differentially regulate transforming growth factor-beta1 autoinduction in proximal tubular epithelial cells. Am J Pathol 2006, 169:1282-1293.

17. Van Beek JP, Kennedy L, Rockel JS, Bernier SM, Leask A: The induction of CCN2 by TGFbeta1 involves Ets-1. Arthritis Res Ther 2006, 8:R36.
18. Zhang W, Wu N, Li Z, Wang L, Jin J, Zha XL: PPARgamma activator rosiglitazone inhibits cell migration via upregulation of PTEN in human hepatocarcinoma cell line BEL-7404. Cancer Biol Ther 2006, 5:1008-1014.

19. De Val S, Ponticos M, Antoniv TT, Wells DJ, Abraham D, Partridge T, BouGharios G: Identification of the key regions within the mouse pro-alpha 2(I) collagen gene far-upstream enhancer. J Biol Chem 2002, 277:9286-9292.

20. Fajardo OA, Thompson K, Parapuram SK, Liu S, Leask A: Mithramycin reduces expression of fibro-proliferative mRNAs in human gingival fibroblasts. Cell Prolif 2011, 44:166-173.

21. Thompson K, Hamilton DW, Leask A: ALK5 inhibition blocks TGFß-induced CCN2 expression in gingival fibroblasts. J Dent Res 2010, 89:1450-1454.

doi:10.1186/1755-1536-5-5

Cite this article as: Sha et al: Loss of PPAR $\gamma$ expression by fibroblasts enhances dermal wound closure. Fibrogenesis \& Tissue Repair 2012 5:5.

\section{Submit your next manuscript to BioMed Central and take full advantage of:}

- Convenient online submission

- Thorough peer review

- No space constraints or color figure charges

- Immediate publication on acceptance

- Inclusion in PubMed, CAS, Scopus and Google Scholar

- Research which is freely available for redistribution

Submit your manuscript at www.biomedcentral.com/submit
C Biomed Central 